was held in great esteem and affection by his colleagues. He received a Presidential Citation from UT President Robert Berdahl in 1996, one of a small handful of faculty members ever to be so honored. He was president of University Co-op for a quarter of a century, and a member of the governing body of the Interscholastic League for 33 years. He was elected and reelected to various councils and committees, and in 1987 he was designated as a distinguished alumnus of the University of Texas.

I think of Emmette principally as a colleague, mentor, and friend, but he was also a dedicated and helpful teacher and he gave endless time and concern to his students, especially to his graduate students. Two of his graduate students established a Redford Prize in the government department, and two of his undergraduate students established a Redford Prize in the LBJ School while he, himself, established a special fund to help needy students in the LBJ School.

Redford's world was public administration and the making of public policy. Indeed he helped make that world. It was Redford as much as any other scholar who taught political scientists that the administrative process, no less than the legislative process, is subject to interestgroup pressures and controls. It was Redford as much as any other political scientist who refocused the concerns of the discipline on public policy. It was Redford as much as any other scholar who erected the public interest as the criterion and objective of policy-making. It was Redford as much as any other political scientist who taught the lawyers that administrative law was the artifact of a political process. Emmette achieved national and international distinction as a scholar. His research and writing were always addressed to the major problems of the nation, especially in the management of the economy; and his books were invariably well received. He was an active member of the American Society for Public Administration and the American Political Science Association, of which he became president in 1960 .
About the time Emmette was thinking of retiring, his grandchildren came to live with him and his wife, Claire. That generated a whole new life and career, and a new beginning as a parent, let alone a grandparent, and he seized upon it with his customary gusto. Once again he lived in the world of the PTA, report cards, driving kids to events-the whole works. At one point, he took on the job of little league coach-with a somewhat marginal success. He would tell the boys to get down low on grounders, and he took them out to eat pizza. It turned out, however, that his coaching skills ran mostly to pizza buying and character building. The team, as I remember, was 0 and 7 on the year.

But the thing I remember best about Emmette Redford was that he and I shared a year-long effort to plan the development of the Lyndon Johnson School of Public Affairs. It was an exhilarating, gratifying, and sometimes frustrating experience, and then, when we completed the plans, a smaller group of us were charged to make a budget and find a dean. It was finally brought into being in 1970 with about 23 students. It has now grown to about ten times that size.

In 1975 Emmette decided to retire, but it didn't really take. He did it by starting an entirely new career teaching in the LBJ School itself. His colleagues spent a lot of money on a retirement party for him, including a half-naked dancing girl, but it was all wasted. He ceased to teach in the government department, but he launched a whole new career as a teacher in the LBJ School. In that role he helped shape the curriculum that he had previously helped to plan. So if we seek a monument for Redford, we have only to look about us, and to reflect that here was a man who planned carefully, administered thoughtfully, and put his plans and principles to a very practical use.

A few years after Emmette became a faculty member in the LBJ School, Harry Middleton and I took him out to lunch one day. By previous and devious design, we pressed upon him the idea that the time had come for somebody to write an ad- ministrative history of the Johnson administration, and we wanted him to tell us whom we might approach to do it. As you can guess, the luncheon ended by Emmette's agreeing to take on the task. He thought he was going to write a book, but it turned out that he not only did that, but took on a considerable task of research administration. The administrative study of the Johnson years finally came to eight or ten volumes, all produced under his authorship or leadership.

Emmette was never solemn about his life or work. He had a nice sense of humor, and he enjoyed many of the absurdities the human condition. Indeed, now and then he created a few himself, and relished the opportunity. There were many Redfords: the teacher, the colleague, the committee man, the planner, the scholar, and the national practitioner. But I remember him best and value him most as a colleague and as a friend. In many ways he will always be with us in the department, in the school, and in the university. But the truth is that he's gone, and there's no way and no reason to avoid saying, "We'll miss you, Emmette. We thank you and we wish you well." William Livingston University of Texas

\section{Rene de Visme Willamson}

Rene de Visme Willamson, professor emeritus of political science at Louisiana State University, died on July 8, 1998. Williamson was a Harvard Ph.D. who held faculty positions at Princeton, Davidson, Beloit, and the University of Tennessee before coming to LSU. He also taught at Johns Hoipkins, Duke, Vanderbilt, and the University of Michigan. He published several books, including Independence and Involvement: A Christian ReOrientation in Political Science and Politics and Protestant Theology: An Interpretation of Tillich, Barth, Bonhoeffer, and Brunner, and a number of articles in leading journals. A marvelous teacher, Dr. Williamson was one of the leading political theorists of his generation, particularly in the field of political theology. He served as editor of the Journal 
of Politics from 1949-53, and was a member of the Executive Council of the American Political Science Association from 1959 to 1961. In 1959 he was elected president of the Southern Political Science Association. He served as chairman of the department of political science at LSU from 1955 to 1963 , and again from 1965 to 1968 . He retired in 1977.

To those of us who were fortunate to have known him, Rene was a man of deep religious conviction. His devotion to his church and to his family, (his wife Virginia and three sons, Parker, Warren, and Roger) was extraordinary. Known for his quick wit, a shameless love of puns, and elegant writing style, Rene also had a strong passion for teach- ing. Teachers, he believed, must a have a strong commitment to their subject matter as well as to their role as mentors. Students, as he wrote in his autobiographical notes, "who have been molded by great teachers can be spotted immediately by their vocabulary, their attitudes, their foes, their commitments, and their points of view." Rene's many students attest to the truth of that observation. He had an equally strong influence on many of his colleagues, particularly young political theorists. As one of them, James Stoner, wrote to me about Rene: "I remember him for his staunch devotion to learning-to the whole range of man's knowledge, of things divine and permanent as well as things human and ephemeral. Unlike so many of even the traditionalists today, he spoke with perfect confidence of a knowable order to the world and had an unshakable sense of right and wrong within it. He understood that laughter and learning went hand in hand, and in my mind I can still hear his laughter."

In our remembrance of him, we celebrate Rene's devotion to the life of the mind and the spirit. In word and deed, he taught us well that in both, but particularly the latter, we can discover, as he wrote, "how sweet, good, exhilarating, abundant and ennobling life can be."

Cecil L. Eubanks Louisiana State University 


\section{APSA BALLOT'99}

\section{NOMINATIONS SOUGHT for APSA OFFICERS and COUNCIL}

The APSA Nominations Committee welcomes your suggestions for candidates for 1999-2000 Council seats and offices. This year, eight Council seats, three vice-presidencies, and the offices of president-elect, Association treasurer, and Association secretary are open. Council members serve staggered three-year terms. The treasurer serves for two years, and the president-elect, vice presidents, and secretary all serve one-year terms.

Please return your list of nominees to APSA by February 16, 1998. You may nominate up to three people for the Council, but only one person each for president-elect, vice president, treasurer, and secretary.

The Nominations Committee will meet in late February to begin compiling a slate of candidates, which they will present to the current Association president no later than April 15, 1999. Elections will be held during the Business Meeting at the 1999 APSA Annual Meeting to be held in Atlanta, September 2-5.

\section{President-Elect}

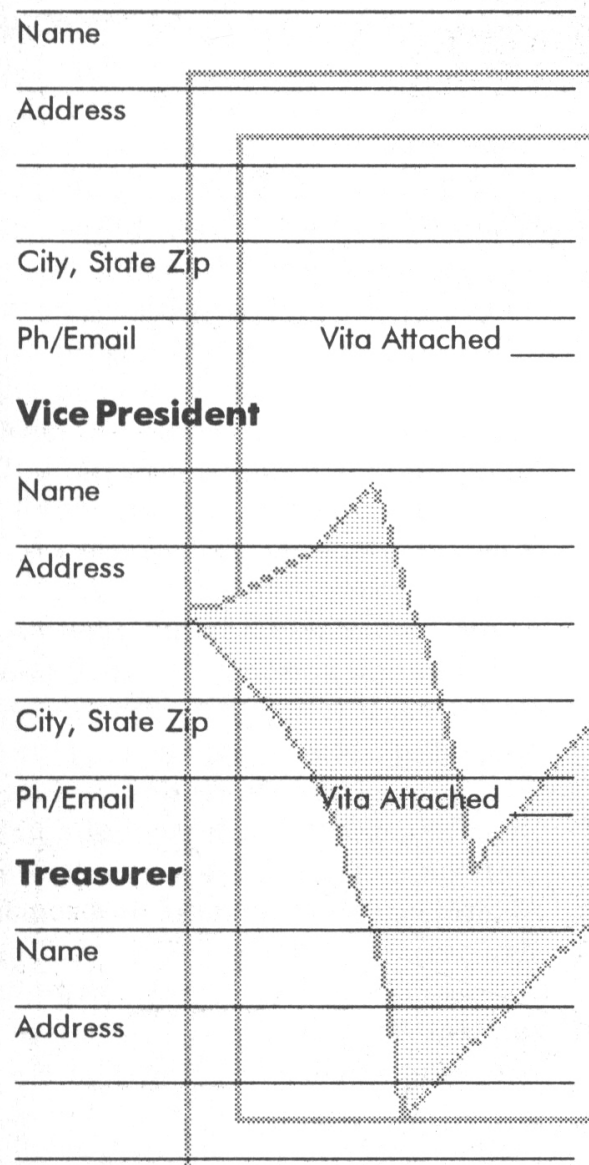

City, State Zip

Ph/Email
Secretary

\section{Name}

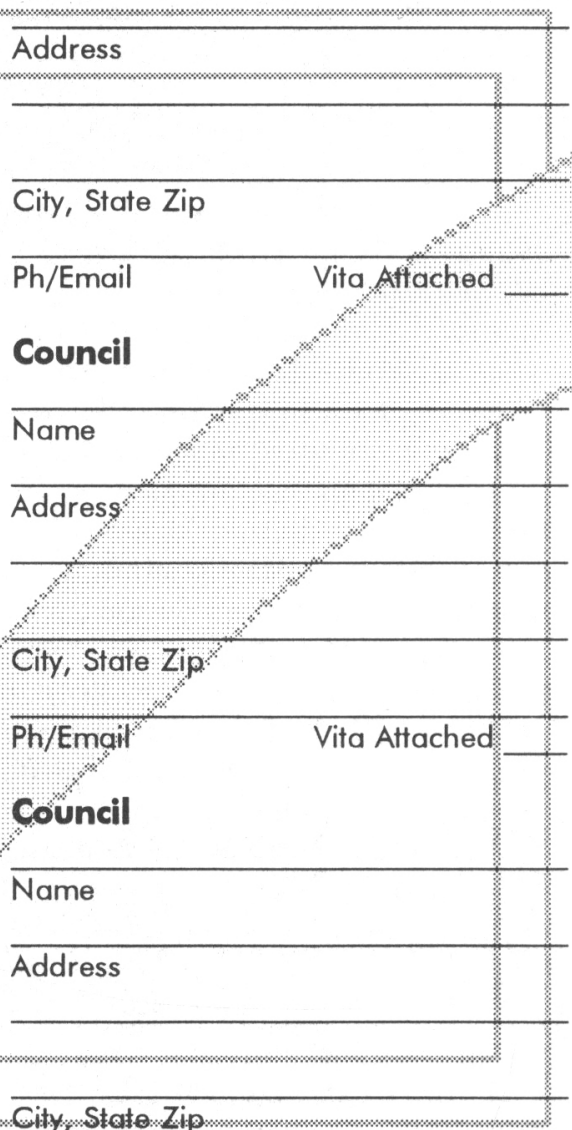

City. State Zip

Ph/Email

Vita Attached

\section{Council}

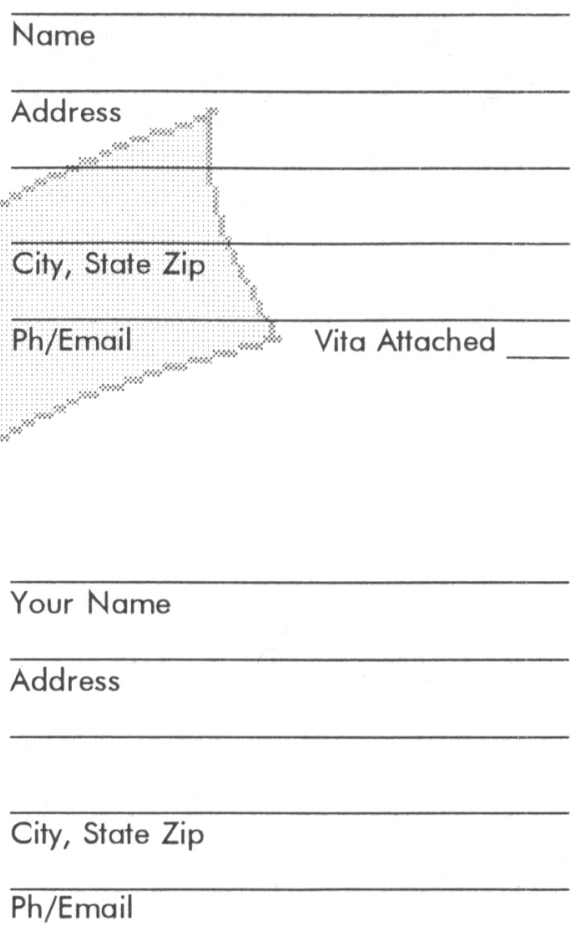

Refurn To:

APSA Ballot

1527 New Hampshire Ave., NW Washington, DC 20036-1206

Fax: 202-483-2657 